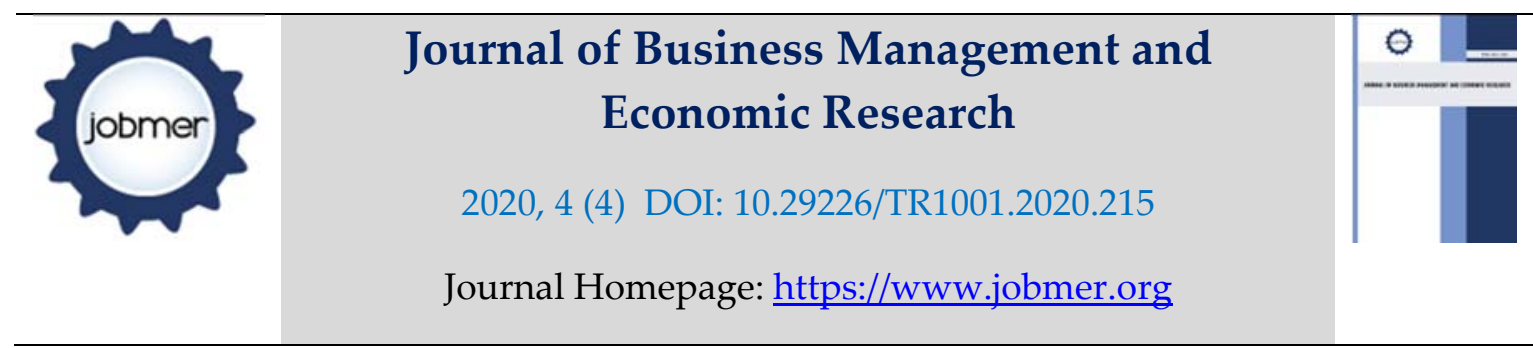

\title{
The Influence of Behavioural Intention to use the ICT Tax System on Tax Compliance Behaviour: The Efficacy of Mediating Effect
}

\author{
Faustine Juma Masunga \\ Business and Entrepreneurship Studies Department \\ National Institute of Transport, P.O.BOX 705, Dar es Salaam, Tanzania \\ masungaf@gmail.com
}

\section{Dr. Joseph Kiria}

Accounting and Finance Department

Mzumbe University, P.O.BOX 6, Morogoro, Tanzania

jkiria@mzumbe.ac.tz

\section{Dr. Moshi James}

Accounting and Finance Department

Mzumbe University, P.O.BOX 6, Morogoro, Tanzania

mjames@mzumbe.ac.tz

\begin{abstract}
The purpose of this study was to estimate the effect of behavioural intention to use the ICT tax system (ICTTs) as a mediating factor on the tax compliance behaviuor in Tanzania. The sample size for this study was made up of 109 taxation students from higher learning institutions. Partial Least Square Structural Equation Modeling was used to analyze the data in two stages; firstly, the measurement model and secondly, the structural model. The study findings depict that the use of the ICTTs to influence compliance behaviour is partially mediated by behavioural intention. Moreover, the results indicate that performance expectancy and effort expectancy have both significant direct and indirect effects on tax compliance behaviour (complementary mediation). That means, in introducing technology, the government has to ensure the technology is simple, and enhance performance and productivity. We recommend the government to continue investing in technology awareness campaign which has an impact on improving tax compliance behaviour for both current and future taxpayers.
\end{abstract}

Keywords: ICT tax system, Tax Compliance Behaviour, Mediator Variable, UTAUT

\section{Suggested Citation:}

Masunga, F. J., Kiria, L. \& James, M. (2020). The Influence of Behavioural Intention to use the ICT Tax System on Tax Compliance Behaviour: The Efficacy of Mediating Effect. Journal of Business Management and Economic Research (JOBMER), Vol: 4, Issue: 4, 351-370. 
Journal of Business Management and Economic Research (JOBMER), Vol.4, Issue.4, pp.351-370

\section{Introduction}

The inception of information technology is perceived as means of bringing great impact in tax compliance behaviour especially in developing countries. In developing world, businesses and agencies of the government are turning into e-government and e-business as an efficient means of accomplishing business transactions.

ICT tax system has brought new slant of managing and doing business and providing services to customers and has modernized and transformed government, business entities in digital form (Kirti and Agrawal, 2014). The application of modern electronic tax system plays an important role in minimizing operational costs and promoting efficiency and effectiveness in service delivery in all walks of life including tax assessment and payment transactions (Harrison \& Nahashon, 2015).

In developing countries about 35 billion US Dollars to 160 billion US Dollars revenue from corporate taxpayers vanished mainly due to low compliance caused by poor application of technologies in tax transactions (Cobham, 2005). Tanzania being one of the developing countries has been structuring tax operations by modernizing and improving the tax system since 1960s to improve tax compliance behaviour. The reforms have been important in driving taxpayers to pay their taxes voluntarily and maximizing the revenue collection (Fossat and Bua, 2013; Kloeden, 2011). Reforms comprehended the introduction of value-added tax, programs to improve taxpayer services and the inception of the ICT tax systems (OECD, 2017).

ICT tax system facilities such the emphasize in adopting and use of Electronic Fiscal Devices (EFDs), the online registration system for Taxpayer Identification, online processing for the motor vehicles (CMVRS), Automated System for Custom Data (ASYCUDA++), the system for drivers' license (CDLS), filing of tax returns electronically and other tax related documents and many more have been introduced by many tax authorities in developing countries (TRA, 2010).

Despite the adoption of several ICT tax system initiatives in developing countries, evidences of changes in voluntary tax compliance behaviour among taxpayers is not well documented (OECD, 2014). Empirical evidences are required in the ICT perspective and tax amenability behaviour in order to support the massive investments in the ICT tax system related decision strategies from current taxpayers and the future taxpayers. 
Journal of Business Management and Economic Research (JOBMER), Vol.4, Issue.4, pp.351-370

This study examined the influence of behavioural intention to use the ICT tax system on tax compliance behaviour in measuring the efficacy of behavioural intention on interceding the associations amongst technology and tax acquiescence behaviour by applying the combined theory of acceptance and use of technology (UTAUT).

Previous studies on the ICT tax system and tax compliance used tax specialists, individual taxpayers and tax officers as unit of analysis (Fagbemi, Uadiale \&Noah, 2011). This study focused on students who were taking taxation as one of their module in accountancy. The use of higher learning students as unit of analysis in this study is justified by the fact that higher learning students are future taxpayers. Examining this group is important as this will figure out whether taxation students have the knowledge on the ICT tax system. Further to this, examining the manner and conduct intention

(BI) to use the ICT tax system in tax transactions on this particular group is important because the way a certain group has an influence over a certain action (SN) and a way a person or society is capable to execute or control over a given behaviour (PBC) the factors of $\mathrm{BI}$ can yield different results in students setting as opposed to working environment (Taylor and Todd, 1995).

Taxpayers tax compliance behaviour is often determined by changes in tax rates, auditing prospect, taxpayers' perception of the government spend on taxes collected, the interest of late payment or submission of tax returns, total ways of particular society, individual and social behaviour (Kirchler, 2007). However some modern factors apart from the listed above have emerged due to the growth of technology. These include and not limited to the level of transforming the ways of tax assessment, collection and accounting from digital business and e-government (Omar et al., 2008). Many studies on the ICT tax system are much prevalent in industrialized countries (Razak \&Adafula, 2013; Admasu \& Daare, 2017). Few are available in developing countries (Rukundo, 2016; Muita, 2011). As such, empirical studies on the influence of the ICT tax system and the effectiveness of mediating effect on tax compliance behaviour still scant.

\subsection{Review of Literature}

\subsubsection{Theoretical review}

This study used UTAUT to explain the ways taxpayers can adopt new technologies and their plan to use. The theory is the blend of a number of models from different theories that address the behaviours of individuals and taxpayers in using technology in tax paying practices. Explaining the 
Journal of Business Management and Economic Research (JOBMER), Vol.4, Issue.4, pp.351-370

concept of using the ICT tax system, UTAUT theory was preferred in this study because it has high volume of variances in describing the behaviours of users in adopting the technology. According to UTAUT theory, four constructs namely performance expectation (PE), effort expectation (EE), social inspiration (SI) and facilitating conditions (FC) form the basis in explaining tax compliance behaviour and intention to use technology. This theory further describes how technology expected to improve the performance and yield more results by changing the behaviour of the users.

It has been identified that the theory of combination is a prevailing model following its usefulness structure with higher explanatory power $\left(\mathrm{R}^{2}\right)$. Despite its usefulness its efficacy and relevance is questionable due to the fact that it fails to examine the direct influence which might reveal new relationships as well as other important factors of the study (Bagozzi, 2007). However using PLSSEM in analyzing the model, it overcomes the problem of this theory following its ability of analyzing total effects (Hair et al., 2017). Performance Expectation is the point in which users are in opinion that practice in a specific technology will facilitate and cause increased efficiency and hence maximize tax compliance level (Hericko et al., 2010). Previous studies revealed that PE has a positive effect on tax compliance behaviour (Hericko et al., 2010). Empirical studies show that performance expectation has a great influence on the behavioural intent to use the ICT tax system (Addo, 2014; Viswanath et al., 2001). Liu (2009) and Park, Yang, and Lehto (2007) show that, PE has statistical significance influence on intention of society to accept and use the ICT tax system. Effort expectation or expectancy (EE) concerns with the extent to which technology is easy to be used by users, the model reported that EE has substantial effect on the adoption and use of technology (Alawadhi \& Morris, 2008; Alshehri \& Drew, 2012). Resulting are the propositions:

$H_{1 a}$ : Performance expectation (PE) on the use of the ICT tax system has a direct positive effect on behavioural intention to use the technology.

$H_{2 a}$ : Effort expectation (EE) on the use of the ICT tax system has a direct positive effect on behavioural intention to use the technology

\subsubsection{Empirical evidence}

Tax compliance is articulated as adhering to all tax duties as the law requires which encompasses the payment the correct assessed taxes (Marti, 2010). It is also the way of submission of all tax documents as required by the tax laws ; declaring all the amount required to be taxed openly and 
Journal of Business Management and Economic Research (JOBMER), Vol.4, Issue.4, pp.351-370

remitting all taxes within the stated time willingly (Singh 2003; Chepkurui et al., 2014; Musimenta et al. 2017). ICT tax system is defined as online method and process which assists taxpayers to access all services electronically without come into contact with tax authorities (Wasao, 2014; Night, 2019). Empirical literatures indicated that behaviour to perform (BI) has a positive relationship on actual usage of the ICT tax system (Makokha \& Ochieng, 2014; D'Ambra, Wilson, \& Akter, 2013). However some studies confirm that there is a negative effect of BI and actual usage (tax compliance behaviour) (Cho et al., 2015). Studies by Meftah, Gharleghi, \& Samadi (201) and Mohammadi (2015) affirm that when users of the ICT tax system are informed and educated of the values of using the ICT tax system in reporting their tax material, assist taxpayers in their records and time of paying taxes then the probability of using the technology increases. This suggests that awareness creation among prospective tax payers and policy makers including higher learning students is of paramount importance to create good future taxpayers who have true picture of the technology used for tax compliance behaviour purpose. Tan (2013) postulates that behavioural intention has a positive effect on the actual usage behaviour of the technology. This means if taxpayers have an intention to use the technology in preparing, paying and submission of tax documents will use the technology repeatedly.

Empirical evidences on the use of technology reveal that social influence plays a fundamental role in influencing individuals in accepting and use of technology (Mandari et al 2017). The central to this idea is; adoption and use of technology depends on how users of the ICT tax system consider individuals and entities close to them will view them as an outcome of using that technology (Viswanath Venkatesh \& Brown, 2001). Social inspiration plays a great role in influencing users to use technology in their business endeavors which in return will have an impact in tax compliance attitude (Viswanath Venkatesh \& Morris, 2000). This notion has been supported by empirical studies like; Fu, Farn, \& Chao, (2006); Hung, Chang, \& Yu, (2006); Hong, \& Kang, (2011). Facilitating condition refers to all necessary facilities and technical assistance to use the technology. The concept implies all resources and support that should be given to individuals to allow easy deployment of the technology for compliance (Brown \& Venkatesh, 2005). There is ample evidence which confirms that facilitating condition affects actual usage behaviour of an individual's tax compliance (Honore, Yaya, Marimon, \& Casadesus, 2013; Mahzan \& Lymer, 2014; Sambasivan, Patrick Wemyss, \& Che Rose, 2010). The following propositions were proposed: 
Journal of Business Management and Economic Research (JOBMER), Vol.4, Issue.4, pp.351-370

$H_{3 a}$ : Social influence (SI) on the use of the ICT tax system has a direct positive effect on behavioural intention to use the technology.

$H_{4 a}:$ Facilitating condition $(F C)$ on the use of the ICT tax system has a direct positive effect on behavioural intention to use the technology

Literatures on the ICT tax system and tax compliance behaviour have been in general directed to eGovernment services, SMEs, tax specialists and relied more on the segmentation approach by studying the direct effects which has a little knowledge contribution (Yildiz 2007; Fagbemi, Uadiale \&Noah, 2011; Razak and Adafula, 2013; Amayi and Clifford, 2013). It is this reason which created a motive to conduct this study under students setting by identifying the efficacy of mediating effect and determining if there are others effects rather that the direct effects (transmittal approach) between the explanatory variables and explained variable (tax compliance behaviour). Through this study the government can come out with strategies to impart awareness for the current and future taxpayers (students). Notwithstanding ample evidence on the influence of the ICT tax systems on the compliance behaviour have been identifies (Kamau, 2014; Mongwaketse, 2015 ;Ngowi, 2014; Ikasu , 2014). Conversely empirical evidence on the efficacy of mediating factor on tax compliance behaviour and the transmittal approach which is a key in determining the indirect effects of independent variables and dependent variables through the mediating variable is insufficient. Studying efficacy of mediating factor of behavioural intention on tax compliance and the indirect effects are of paramount significance as they add more knowledge on understanding nature of the effects and challenges the studies which relied on direct effects only; henceforth the basis of this study.

\section{Material and Methods}

A survey design was adopted in this study where data were collected at once and intended to test and analyze research model. Development of survey instrument was informed by relevant measurement items adapted from previous relevant studies on identifying suitable and valid measurement items. A self-administered questionnaire, in particular, close-ended type structure was preferred in this study by virtue of its ability to improve responses relative to open ended questions. The level of influence was anchored to five -point Likert scale, in which 1 indicated strongly disagree 
Journal of Business Management and Economic Research (JOBMER), Vol.4, Issue.4, pp.351-370

and 5 strongly agree. This study took taxation students from higher learning institutions namely Tumaini University and National Institute of Transport as the sample with total of 109 respondents. Data were analysed using Partial Least Square Structural equation modeling (PLS-SEM) which consists of two stages: the measurement model and the structural model (Henseler,Ringle, \& Sarstedt, 2015).

PLS-SEM works efficiently on small sample sizes and complex models and relevant for determining direct and indirect effect (Chin \& Newsted, 1999; Hui \& Wold, 1982). Sample selection was based on rule of thumb which is equivalent to saying that the minimum sample size should be 10 times the maximum number of arrowheads pointing at a latent variable anywhere in the PLS path model (Hair et al., 2016). In examining the influence of behavioural intention to use the ICT tax system on tax compliance behaviour, two modes involved as proposed in PLS-SEM model that are measurement models and structural model as presented in the data. However more emphasis was in the effect of BI as the mediator between UTAUT constructs and tax compliance behaviour and the indirect effects. The following items were reflectively measured; internal consistency reliability using composite reliability (CR), the reliability of indicators (MV) by employing the indicators' outer loadings (OL), and validity of indicators to constructs $(\mathrm{CV})$ using average variance extracted (AVE) and validity of constructs to constructs (DV) using heterotrait monotrait ratio (HTMT).The constructs association were tested using path coefficients, collinearity using variance inflation factor (VIF) and the indirect effects of ICT on tax compliance behaviour (TCB) through behaviour intention (BI).

Indicators of a reflective construct are treated as different (alternative) approaches to measure the same construct (Henseler et al., 2015). Outer loadings of the indicators and average variance extracted used to validate convergent validity of reflective independent variables. On the other hand discriminant validity implies that a construct is exclusive and captures phenomena not represented by other constructs in the model (Voorhees, Brady, Calantone, \& Ramirez, 2016). To evaluate discriminant validity; heterotrait-monotrait ratio was used. HTMT was more preferred to assess discriminant validity because the other two methods prove failure and not recommended in recent studies (Henseler et al., 2015). Explicitly, cross-loadings fail to indicate a lack of discriminant validity when two constructs are dreamily correlated. Correspondingly, the Fornell-Larcker criterion performs very poorly, especially when indicator loadings of the constructs under consideration differ only slightly (Voorhees et al., 2016). In addition before data analysis, data were screened for 
Journal of Business Management and Economic Research (JOBMER), Vol.4, Issue.4, pp.351-370

missing values and other problems such as same values for all questions, inappropriate value assignment and a total of 109 questionnaire remained for analysis.

\section{Results and Discussion}

\subsection{Results}

\subsubsection{Measurement Model (Reflective Measurement)}

In the first stage; this study tested items loading with significant t-statistics and $p$ values (Lowry \& Gaskin, 2014). Where the empirical t-value greater than the critical value; we concluded that the coefficient was statistically significant at a certain error probability. The common used and suggested critical values for two-tailed tests in social science studies are 1.65 (significance level $=10 \%$ ), 1.96 (significance level $=5 \%$ ), and 2.57 (significance level $=1 \%$ ) (Hair et al., 2016). Table 1 show that all reflective indicators of the constructs are statically significant except one indicator of social influence indicator that is (t-value $>1.96$ and $p$-value $<0.05)$. For that reason the results confirm strong convergent validity in the model.

Table1. Mean, STDEV, T-Values, P-Values of Indicators

\begin{tabular}{|c|c|c|c|c|c|}
\hline & $\begin{array}{l}\text { Original } \\
\text { Sample (O) }\end{array}$ & $\begin{array}{l}\text { Sampl } \\
\text { e } \\
\text { Mean } \\
(\mathrm{M})\end{array}$ & $\begin{array}{l}\text { Standard } \\
\text { Deviation } \\
\text { (STDEV) }\end{array}$ & $\begin{array}{l}\text { T Statistics } \\
\text { (|O/STDEVI) }\end{array}$ & P Values \\
\hline bi $<-$ BI & 1.000 & 1.000 & 0.000 & & \\
\hline eff_1 $1<-$ EE & 0.805 & 0.797 & 0.090 & 8.944 & 0.000 \\
\hline eff_2 $<-$ EE & 0.791 & 0.777 & 0.086 & 9.193 & 0.000 \\
\hline eff_3 $<-$ EE & 0.817 & 0.810 & 0.068 & 12.001 & 0.000 \\
\hline fac_1 $<-$ FC & 0.744 & 0.699 & 0.182 & 4.085 & 0.000 \\
\hline fac_2 $2<-$ FC & 0.879 & 0.830 & 0.172 & 5.096 & 0.000 \\
\hline fac_3 $<-$ FC & 0.757 & 0.692 & 0.223 & 3.393 & 0.001 \\
\hline perf_1 $1<-$ PE & 0.904 & 0.890 & 0.118 & 7.686 & 0.000 \\
\hline perf_2 $<-$ PE & 0.617 & 0.563 & 0.215 & 2.873 & 0.004 \\
\hline perf_3 <- PE & 0.759 & 0.699 & 0.187 & 4.069 & 0.000 \\
\hline so_1 $<-$ SI & 0.889 & 0.768 & 0.265 & 3.360 & 0.001 \\
\hline so_ $2<-$ SI & 0.515 & 0.458 & 0.338 & 1.525 & 0.128 \\
\hline so_3<-SI & 0.764 & 0.652 & 0.260 & 2.935 & 0.003 \\
\hline tcb_1<- TCB & 0.613 & 0.599 & 0.116 & 5.267 & 0.000 \\
\hline tcb_2 <- TCB & 0.922 & 0.920 & 0.016 & 56.539 & 0.000 \\
\hline tcb_3<- TCB & 0.892 & 0.893 & 0.031 & 28.710 & 0.000 \\
\hline
\end{tabular}




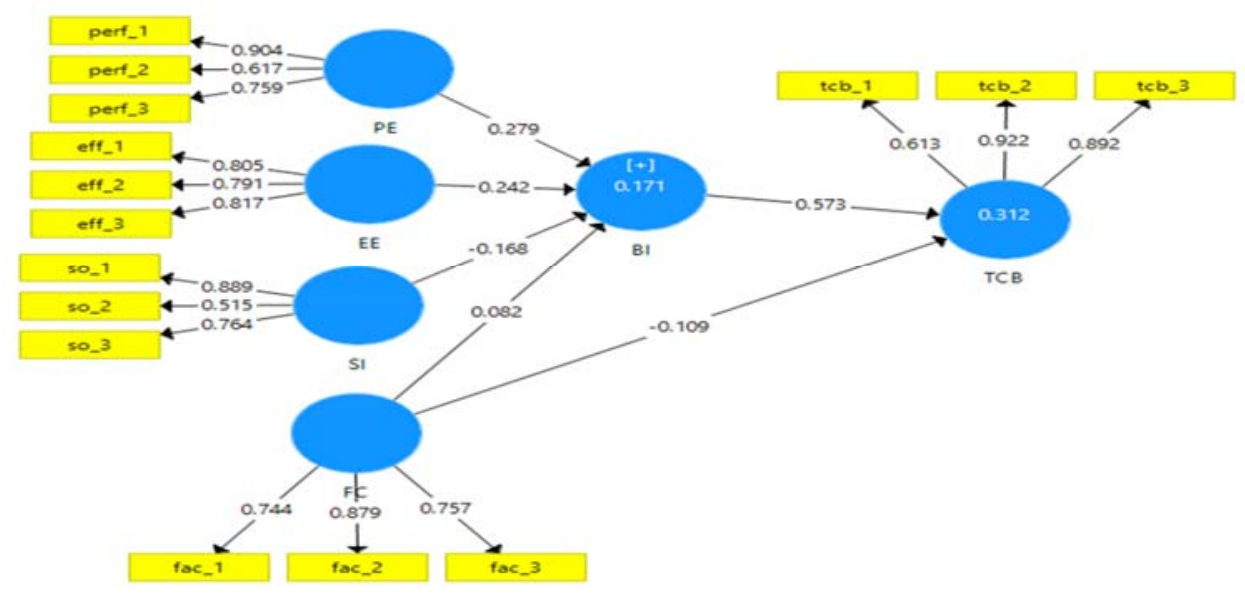

Figure 1. Measurement and structural model evaluation

\subsubsection{Discriminant validity evaluation}

In evaluating discriminant validity); the heterotrait-monotrait ratio (HTMT) was used. HTMT is the average of all relationships of indicators across concepts. It is the heterotrait-heteromethod correlations relative to the geometric mean of the average associations of indicators measuring the same construct (Henseler et al., 2015). HTMT emphasizes on the true relationship between two concepts if were persistently measured. Based on previous studies' results, Henseler et al. (2015) suggest a threshold value of 0.85 to 0.9 . Threshold above 0.9 suggests a lack of discriminant validity. HTMT was converted by using the following formula:

HTMT of the constructs $=\underline{\text { between-trait correlations }}=\underline{\text { Mean of Between trait correlation }}$

Within trait correlation $\quad G M$ of the average correlations

HTMT ration $=(\underline{0.332+0.727+0.594+0.210+0.122+0.469+0.606)}=0.437 / 0.513$

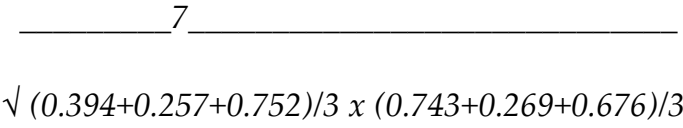

Hence; HTMT $=0.852 \approx \approx 0.85$. 
Journal of Business Management and Economic Research (JOBMER), Vol.4, Issue.4, pp.351-370

The value is higher as suggested in the threshold. This means the results strongly confirm the discriminant validity of the constructs. The calculated result indicated that constructs are really distinctive from other constructs by empirical standards (table 2).

Table 2. Evaluation for Discriminant Validity

\begin{tabular}{|l|r|r|l|l|l|l|}
\hline & & & & & & \\
\hline & BI & EE & FC & PE & SI & TCB \\
\hline BI & & & & & & \\
\hline EE & 0.394 & & & & & \\
\hline FC & 0.257 & 0.752 & & & & \\
\hline PE & 0.332 & 0.727 & 0.594 & & & \\
\hline SI & 0.210 & 0.903 & 1.133 & 0.743 & & \\
\hline TCB & 0.606 & 0.469 & 0.122 & 0.269 & 0.676 & \\
\hline
\end{tabular}

Where: BI: Behaviour Intention; PE: Performance Expectancy; EE: Effort Expectancy; FC: Facilitating Condition; SI: Social Influence; TCB: Tax Compliance Behaviour.

\subsubsection{Test for internal consistency reliability}

In testing internal consistency reliability, composite reliability was preferred for this study due to its sensitivity of overcoming the problem of cronbach's alpha of conservative measure of reliability. Cronbach's alpha has a weakness of producing low reliability values (Wong, 2013). It tends to underestimate the internal consistency reliability. Values of 0.70 to 0.90 of composite reliability are regarded as statistically significant and values below 0.6 are an indicative of lack of internal reliability ((Drolet\& Morrison, 2001; Hayduk \& Littvay, 2012). Basing on our results as indicated on table 3 all the reflective constructs have a value above 0.7 which confirm strong internal reliability except for performance expectancy (PE) and social influence (SI) which have moderate reliability. 
Table 3. Assessment of consistency reliability

\begin{tabular}{|l|l|r|r|r|}
\hline & \multicolumn{2}{|l|}{$\begin{array}{l}\text { Cronbach's } \\
\text { Alpha }\end{array}$} & \multicolumn{1}{l|}{ rho_A } & \multicolumn{2}{l|}{$\begin{array}{l}\text { Composite } \\
\text { Reliability }\end{array}$} & \multicolumn{2}{l|}{$\begin{array}{l}\text { Exerage Variance } \\
\text { Extracted (AVE) }\end{array}$} \\
\hline BI & 1.000 & 1.000 & 1.000 & 1.000 \\
\hline EE & 0.732 & 0.742 & 0.724 & 0.572 \\
\hline FC & 0.719 & 0.793 & 0.728 & 0.687 \\
\hline PE & 0.716 & 0.857 & 0.641 & 0.541 \\
\hline SI & 0.617 & 0.777 & 0.631 & 0.605 \\
\hline TCB & 0.756 & 0.845 & 0.781 & 0.562 \\
\hline
\end{tabular}

\subsubsection{Mediation analysis}

In evaluating the mediating effect of BI on UTAUT constructs and Tax compliance behaviour the test for mediation is of paramount importance. Bootstrapping is recommended approach for evaluating mediation using variance accounted for (VAF). Bootstrapping is robust when applied to large and small sample sizes and no distribution assumption is required (Hair et al., 2016) Mediator is a variable that accounts for part or all of the relationship between predicator and outcome (Baron and Kenny 1986, p. 1176). Mediation can be full, partial or no mediation at all that is when VAF is greater than 0.8 or $80 \%$ there is full mediation, value $0.2 \leq \mathrm{VAF} \leq 0.8$ indicate partial mediation and value less than 0.2 means no mediation (Shrout \&Bolger,2002; Zhao, Lynch \& Chen, JCR, 2010). With full mediation we mean a situation in mediation analysis that occur when the mediated effect is significant but not the direct effect (indirect only mediation). Partial mediation means a mediator variable partially explains the relationship between an exogenous and an endogenous construct. Partial mediation can be in the form of complementary and competitive mediation, depending on the relationship between the direct and indirect effects.

Recommended formula for testing mediation: VAF $=\left(P_{12} \cdot P_{23}\right)$

$$
\left(P_{12} . P_{23}+P_{13}\right)
$$

Where by $P_{1}$ and $P_{2}=$ direct effect, $P_{3}=$ indirect effect $)$

$$
\text { Or } \quad Z^{*}(d)=\underline{\beta^{*}(d)-\alpha}
$$

$\mu^{*}(d)$ 
Journal of Business Management and Economic Research (JOBMER), Vol.4, Issue.4, pp.351-370

in which $Z *(d)$ is the $Z$ value for the $d^{\text {th }}$ bootstrap sample, $\beta$ is the original sample estimate of the mediator effect $\mathrm{P}_{12}, \mathrm{P}_{23}$ and $\beta^{*}(\mathrm{~d}), \mu^{*}(\mathrm{~d})$ are the estimated value and standard error of $\mathrm{P}_{12,} \mathrm{P}_{23}$ for the $\mathrm{d}^{\text {th }}$ bootstrap sample. The test for mediation uncovered the following results: There is significance direct effect of performance expectancy, effort expectancy and facilitating condition on behavioural intention to use the ICT tax system $(\beta=0.279 ; \mathrm{P}<0.05),(\beta=0.242 ; \mathrm{P}<0.05)$ and $(\beta=0.082 ; \mathrm{P}<0.05$ respectively. There was significant direct effect of behavioural intention on tax compliance behaviour $(\beta=0.573 ; \mathrm{P}<0.05)$. When controlling for mediator variable behavioural intention (shown in figure 2) the direct effect of UTAUT constructs on tax compliance reduced by $\beta=0.329$ that is both constructs of UTAUT on tax compliance behaviour yield $\beta=0.244$ while that of mediator on tax compliance behaviour is $\beta=0.573$. This indicates that behavioural intention to use the ICT tax system is partially mediated by behavioural intention to use the technology. The essence of testing the relationship without mediator variable is to see how much of the direct effect does indirect effect absorb to see if there is partial or full mediation.

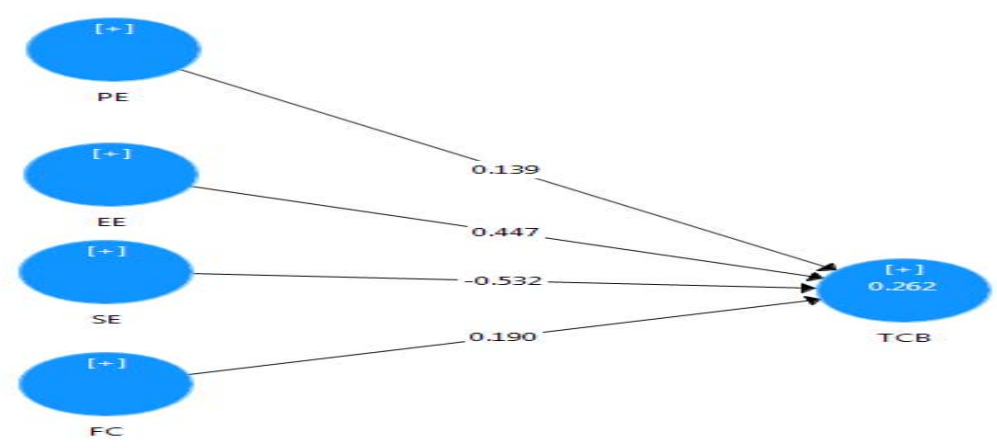

Figure 2: Test for significance of direct relationship without mediator variable 
Journal of Business Management and Economic Research (JOBMER), Vol.4, Issue.4, pp.351-370

\subsubsection{Assessing the indirect effects}

The indirect effects involve many associations with at least one mediator variable linking the associations (Hair et al., 2016). The essence of evaluating the indirect effects is to identify which antecedent variable(s) has a strong influence on the outcome variable for decision making. The results of our study indicate that performance expectancy plays a great role on influencing compliance behaviour through the mediator variable (behavioural intention). That is, performance expectancy has the strongest indirect effect on tax compliance behaviour. On other way, the effect between performance expectancy and tax compliance behaviour is mediated by behavioural intention followed by effort expectancy on tax compliance behaviour (table 4). However insignificant indirect effect between facilitating condition and tax compliance behaviour through behavioural intention was identified followed by social influence on tax compliance behaviour.

Table 4. Mean, STDEV, T-Values, P-Values of Indicators

\begin{tabular}{|l|r|r|r|r|}
\hline & $\begin{array}{l}\text { Original } \\
\text { Sample (O) }\end{array}$ & $\begin{array}{l}\text { Standard Deviation } \\
\text { (STDEV) }\end{array}$ & $\begin{array}{l}\text { T Statistics } \\
\text { (IO/STDEVI) }\end{array}$ & P Values \\
\hline EE -> BI -> TCB & 0.139 & 0.068 & 2.045 & 0.041 \\
\hline FC $>$ BI $>$ TCB & 0.047 & 0.083 & 0.564 & 0.573 \\
\hline PE -> BI -> TCB & 0.160 & 0.070 & 2.305 & 0.022 \\
\hline SI -> BI -> TCB & -0.096 & 0.097 & 0.989 & 0.323 \\
\hline
\end{tabular}

\subsubsection{Structural model evaluation (Test for constructs Measurement)}

The structural model evaluation involved the measurement of one construct to another construct within the model. The following items were tested; analysis of mediation, Path coefficients, Coefficient of determination $\left(\mathrm{R}^{2}\right)$, collinearity by applying the variance inflation factor (VIF) and evaluation of direct and indirect relationship. When interpreting the results of a path model, it was of paramount significance to test the significance of all structural model relationships using $t$ values, $p$ values, and the bootstrap confidence intervals. The bootstrap confidence interval allows testing whether a path coefficient is significantly different from zero. It provides information on the stability of the estimated coefficient by offering a range of conceivable population values for the parameter dependent on the variation in the data and the sample size. 
Journal of Business Management and Economic Research (JOBMER), Vol.4, Issue.4, pp.351-370

\subsubsection{Collinearity evaluation}

Multicollinearity or simply collinearity also was tested, this occurs when two variables are highly associated. Collinearity of indicators were assessed using indicator's Variance Inflation factor (VIF) and the value should be lower than 5. In PLS-SEM perspective, a tolerance value of 0.20 or lower and a VIF value of 5 and higher consistently show a potential collinearity problem (Hair et al., 2011). More precisely, an indicator's VIF level of 5 indicates that $80 \%$ of its variance is accounted for by the remaining indicators associated with the same construct. Collinearity valuation of our model shows that all the construct values of predictor variables are below 3.0 (as indicated in table 4).

Table 5. Collineriaty validation

\begin{tabular}{|l|r|l|l|l|l|l|l|}
\hline & BI & EE & FC & PE & SI & \multicolumn{1}{l|}{ TCB } & TEC \\
\hline BI & & & & & & 1.239 & \\
\hline EE & 1.929 & & & & & & \\
\hline FC & 3.580 & & & & & 1.363 & \\
\hline PE & 2.153 & & & & & & \\
\hline SI & 2.686 & & & & & & \\
\hline TCB & & & & & & & \\
\hline TEC & 1.813 & & & 1.000 & & 1.425 & \\
\hline
\end{tabular}

\subsubsection{Coefficient of determination $\left(\mathbf{R}^{2}\right)$}

$\mathrm{R}^{2}$ measures the model's predictive power and is computed as the squared correlation among the specific endogenous construct's actual and predicted values (Rigdon, 2012; Sarstedt, Ringle, Henseler, \& Hair, 2014). The coefficient represents the exogenous latent variables' combined effects on the endogenous latent variable. That is, the coefficient represents the amount of variance in the endogenous constructs explained by all of the exogenous constructs linked to it. PLS-SEM aims at maximizing the $\mathrm{R}^{2}$ values in the effect of latent variable(s) in the path model. The exact analysis of the $\mathrm{R}^{2}$ value depends on the certain model and research discipline; generally $\mathrm{R}^{2}$ values of $0.75,0.50$, or 0.25 for the outcome construct can be described as respectively substantial, moderate, and weak. In the case of our model exogenous constructs explain about $31.2 \%$ to endogenous constructs which is moderate as suggested in a critical value (figure 1). 
Journal of Business Management and Economic Research (JOBMER), Vol.4, Issue.4, pp.351-370

\subsection{Discussions of the Findings}

The purpose of this paper was to study the influence of behavioural intention to use the ICT tax system on tax compliance behaviour, and, more specifically survey the efficacy of mediating factors on behavioural intention to use technology and identifying the indirect effects. The analyses of statistical results show that performance expectancy (PE), effort expectancy (EE) and facilitating condition influence behavioural intention (BI) to use the ICT tax system. The results are consistent with the findings from the previous studies e.g. Bhuasiri et al., 2016; Carter, \& McBride, 2010; Shafi \& Weerakkody, 2009). The findings support the generalizability of results to other backgrounds and context for this reason; we accept the alternative hypotheses $\mathrm{H}_{1 a}, \mathrm{H}_{2 b}$ and $\mathrm{H}_{4 a}$. Users' behaviour on the use of ICT depends on how well the technology is simple to be used, can increase productivity and performance and has the required facilities (Sumak, Polancic, \& Hericko, 2010; Viswanath Venkatesh \& Brown, 2001). By contrast, social influence (SI) on behavioural intention (BI) did not support the proposition $\left(\mathrm{H}_{3 \mathrm{a}}\right)$. As such, the results of SI on BI to use the ICT tax system were not statistically significant. Mandari et al. (2017), Gu, Lee, \& Suh, (2009) had similar results of SI on BI. Thus; the influence of other groups like co-users and important groups is insignificant on the behavioural intention to use the ICT tax system (Mandari et al., 2017).

The results further indicated that PE has a strongest statistical significance influence on intention to use ICT $(\beta=0.279)$ followed by effort expectancy (EE) $(\beta=0.242)$ and facilitating condition (FC) $(\beta=0.082)$. Similar results were achieved on the indirect effects which indicated that, performance expectancy has the strongest significant indirect effect on tax compliance behavioural through behavioural intention followed by effort expectancy. This situation is what referred to complementary mediation (both direct and indirect effects are significant and are in the same path). The result that stands out here advocates that the use of technical know-how depends on how well the technology can perform, brings about changes and increase productivity (Yuen, Yeow, Lim, \& Saylani, 2010). That means, in designing or introducing the technology, authorities, governments, private and public organisations need to emphasize on the performance of the technology and how well the technology is understood and easy to be used by the users. The findings confirm empirical studies which concluded that PE is the strongest antecedent of behaviour intention (Anderson, Schwager, \& Kerns, 2006; Bandyopadhyay \& Katherine, 2007) 
Journal of Business Management and Economic Research (JOBMER), Vol.4, Issue.4, pp.351-370

The effect of behavioural intention to use the ICT tax system on tax compliance behaviour also became evident in this study $(\beta=0.573)$. Result that stands out here suggests that in order to determine whether users of the ICT tax system accept and use the technology, their intention should be converted to actual use, that is, tax compliance behaviour (Delone \& McLean, 2003). The transforming of BI into tax compliance behaviour (actual use) involves the measuring the correlation between behavioural intention and tax compliance behaviour. Previous studies argued that BI has a positive relationship on tax compliance behaviour (Venkatesh \& Davis, 2000). The present study support previous studies by indicating that BI has a positive relationship with tax compliance behaviour $(\beta=0.573$ ). Regarding the efficacy of mediating factors, the findings indicate that the influence of the ICT tax systems on tax compliance behaviour is partially mediated by behavioural intention (BI) (24.4\%) which describes the source and nature of relationship.

\subsection{Conclusion and Recommendation}

The purpose of this paper was to study the influence of behavioural intention to use the ICT tax system on tax compliance behaviour, contributes to the debate and literature on e-tax system and tax compliance behaviour and, more specifically provides useful insights on the efficacy of mediating factors on social intention to use technology and determine the indirect effects. The study objectives were explored through questionnaire in which 109 students from higher learning institutions were involved in the survey. Data were analyzed using Partial Least Square Structural equation modeling (PLS-SEM) which consists of two stages: the measurement model and the structural model. Results show that the influence of ICT tax systems, more specifically e-tax system, on tax compliance is partially mediated by behavioural intention to use the technology. The results further indicate that performance expectancy and effort expectancy have significant indirect effects on tax compliance behaviour through the behavioural intention. The findings suggest that tax compliance behaviour is directly and indirectly influenced by intention to use the ICT tax system. Based on this conclusion, we advance a need for government to invest more on awareness creation campaigns regarding usefulness of the ICT tax systems to both, current taxpayers, students as future taxpayers and the government. We also advise the government to focus more on performance, simplest and productivity when designing the system.

The findings of this study call for a need for the government to emphasize and prepare a complying behaviour and environment for future taxpayers by training and educating students especially those 
Journal of Business Management and Economic Research (JOBMER), Vol.4, Issue.4, pp.351-370

in higher learning institutions. It is important that they are trained on the importance of using technology on tax payment, as this may in the future minimize the extent of non-compliance behaviuor. Admittedly, frustrating experience encountered while introducing electronic fiscal devices (exemplar the Electronic Fiscal Device) and many other tax reforms in Tanzania could be leveraged in presence of this kind of awareness. Our study appreciates and underlines the importance and influence of e-tax system on tax compliance behaviuor. Currently, it is large taxpayers only who are fully fledged with e-tax system for compliance purpose. This calls for reviewing our tax regime and policies to extend the application of e-tax system and its practices beyond large tax payers.

This study is not without limitations. Although inherent limitations of a survey apply to this study, two specific limitations need to be articulated. The first limitation concerns the possibility to generalize the study findings outside Tanzania following concentration of the study in Tanzania as the study area, and using a limited unit of analysis. We suggest future studies to take a comparative approach (in which, a number of countries will be studied on a comparative basis) and extended units of analyses to improve the results.

A second limitation is the nature of our study. We used self-administered questionnaire that do not allow intervention. Approach that allows minimum intervention would have helped us in gaining more insights especially on the responses with regard to factors responsible for non-compliance. Further to this, the study was quantitative in nature which is deficient in exploring research problem in an in-depth manner. We propose future studies to consider combining both, quantitative and qualitative techniques in a single study to complement the weaknesses of the quantitative approach.

\section{References}

AlAwadhi, S., \& Morris, A. (2008, January). The Use of the UTAUT Model in the Adoption of E-government Services in Kuwait. In Proceedings of the 41st annual Hawaii international conference on system sciences (HICSS 2008) (pp. 219-219). Ieee.

Alshehri, M., Drew, S., Alhussain, T., \& Alghamdi, R. (2012). The Effects of Website Quality on Adoption of E-Government Service: AnEmpirical Study Applying UTAUT Model Using SEM. arXiv preprint arXiv:1211.2410.

Attuquayefio, S., \& Addo, H. (2014). Using the UTAUT model to analyze students' ICT adoption. International Journal of Education and Development using ICT, 10(3). 
Journal of Business Management and Economic Research (JOBMER), Vol.4, Issue.4, pp.351-370

Bagozzi, R. P. (2007). On the meaning of formative measurement and how it differs from reflective measurement: Comment on Howell, Breivik, and Wilcox (2007).

Brown, S. A., \& Venkatesh, V. (2005). Model of adoption of technology in households: A baseline model test and extension incorporating household life cycle. MIS quarterly, 29(3).

Chin, W. W., \& Newsted, P. R. (1999). Structural equation modeling analysis with small samples using partial least squares. Statistical strategies for small sample research, 1(1), 307-341.

Chin, W. W., Kim, Y. J., \& Lee, G. (2013). Testing the differential impact of structural paths in PLS analysis: A bootstrapping approach. In New perspectives in partial least squares and related methods (pp. 221-229). Springer, New York, NY.

Cho, Y. C., \& Sagynov, E. (2015). Exploring factors that affect usefulness, ease of use, trust, and purchase intention in the online environment. International Journal of Management \& Information Systems (IJMIS), 19(1), 21-36.

Cobham, A. (2005). Tax evasion, tax avoidance and development finance. Queen Elizabeth House, Série documents de travail, 129, 1-20.

D'Ambra, J., Wilson, C. S., \& Akter, S. (2013). Application of the task-technology fit model to structure and evaluate the adoption of E-books by A cademics. Journal of the American society for information science and technology, 64(1), 48-64.

Fu, J. R., Farn, C. K., \& Chao, W. P. (2006). Acceptance of electronic tax filing: A study of taxpayer intentions. Information $\mathcal{E}$ Management, 43(1), 109-126.

Gupta, K. P., Singh, S., \& Bhaskar, P. (2016). Citizen adoption of e-government: a literature review and conceptual framework. Electronic Government, an International Journal, 12(2), 160-185.

Gwaro, O. T., Maina, K., \& Kwasira, J. (2016). Influence of online tax filing on tax compliance among small and medium enterprises in Nakuru Town, Kenya. IOSR Journal of Business and Management, 2(3), 54-65.

Hair Jr, J. F., Hult, G. T. M., Ringle, C., \& Sarstedt, M. (2016). A primer on partial least squares structural equation modeling (PLS-SEM). Sage publications.

Hair Jr, J. F., Sarstedt, M., Ringle, C. M., \& Gudergan, S. P. (2017). Advanced issues in partial least squares structural equation modeling. Sage Publications.

Hair, J. F., Ringle, C. M., \& Sarstedt, M. (2013). Partial least squares structural equation modeling: Rigorous applications, better results and higher acceptance. Long range planning, 46(1-2), 1-12.

Hayduk, L. A., \& Littvay, L. (2012). Should researchers use single indicators, best indicators, or multiple indicators in structural equation models?. BMC medical research methodology, 12(1), 159.

Henseler, J., Dijkstra, T. K., Sarstedt, M., Ringle, C. M., Diamantopoulos, A., Straub, D. W., ... \& Calantone, R. J. (2014). Common beliefs and reality about PLS: Comments on Rönkkö and

Henseler, J., Ringle, C. M., \& Sarstedt, M. (2015). A new criterion for assessing discriminant validity in variance-based structural equation modeling. Journal of the academy of marketing science, 43(1), 115135.

Hui, B. S., \& Wold, H. (1982). Consistency and consistency at large of partial least squares estimates. Systems under indirect observation, part II, 119-130. 
Journal of Business Management and Economic Research (JOBMER), Vol.4, Issue.4, pp.351-370

Hung, S. Y., Chang, C. M., \& Yu, T. J. (2006). Determinants of user acceptance of the e-Government services: The case of online tax filing and payment system. Government Information Quarterly, 23(1), 97-122.

Im, I., Hong, S., \& Kang, M. S. (2011). An international comparison of technology adoption: Testing the UTAUT model. Information \& management, 48(1), 1-8.

Kirchler, E. (2007). The economic psychology of tax behaviour. Cambridge University Press.

Lowry, P. B., \& Gaskin, J. (2014). Partial least squares (PLS) structural equation modeling (SEM) for building and testing behavioural causal theory: When to choose it and how to use it. IEEE transactions on professional communication, 57(2), 123-146.

Liu, C. (2009). Mobile data service demographics in urban China. Journal of Computer Information Systems, $50(2), 117-126$.

Mahzan, N., \& Lymer, A. (2014). Examining the adoption of computer-assisted audit tools and techniques: Cases of generalized audit software use by internal auditors. Managerial Auditing Journal, 29(4), 327-349.

Makokha, M. W., \& Ochieng, D. O. (2014). Assessing the success of ICT's from a user perspective: Case study of Coffee Research Foundation, Kenya. Journal of Management and Strategy, 5(4), 46.

Night, S., \& Bananuka, J. (2019). The mediating role of adoption of an electronic tax system in the relationship between attitude towards electronic tax system and tax compliance. Journal of Economics, Finance and Administrative Science.

Park, J., Yang, S., \& Lehto, X. (2007). Adoption of mobile technologies for Chinese consumers. Journal of Electronic Commerce Research, 8(3).

Petnji Yaya, L. H., Marimon, F., \& Casadesus, M. (2013). The contest determinant of delight and disappointment: a case study of online banking. Total Quality Management \& Business Excellence, 24(11-12), 1376-1389.

Shrout, P. E., \& Bolger, N. (2002). Mediation in experimental and nonexperimental studies: new procedures and recommendations. Psychological methods, 7(4), 422.

Šumak, B., Polancic, G., \& Hericko, M. (2010, February). An empirical study of virtual learning environment adoption using UTAUT. In 2010 Second international conference on mobile, hybrid, and online learning (pp. 17-22). IEEE.

Taylor, S., \& Todd, P. A. (1995). Understanding information technology usage: A test of competing models. Information systems research, 6(2), 144-176.

TRA. (2010e), “Tax modernization program implementation support mission. ICT performance report for period ending September 2010". Information and Communication Technology Department, Tanzania Revenue Authority.

Venkatesh, V., \& Brown, S. A. (2001). A longitudinal investigation of personal computers in homes: adoption determinants and emerging challenges. MIS quarterly, 71-102

Venkatesh, V., \& Morris, M. G. (2000). Why don't men ever stop to ask for directions? Gender, social influence, and their role in technology acceptance and usage behaviour. MIS quarterly, 115-139. 
Journal of Business Management and Economic Research (JOBMER), Vol.4, Issue.4, pp.351-370

Voorhees, C. M., Brady, M. K., Calantone, R., \& Ramirez, E. (2016). Discriminant validity testing in marketing: an analysis, causes for concern, and proposed remedies. Journal of the Academy of Marketing Science, 44(1), 119-134.

Wong, K. K. K. (2013). Partial least squares structural equation modeling (PLS-SEM) techniques using SmartPLS. Marketing Bulletin, 24(1), 1-32.

Yildiz, M. (2007). E-government research: Reviewing the literature, limitations, and ways forward. Government information quarterly, 24(3), 646-665.

Zhao, X., Lynch Jr, J. G., \& Chen, Q. (2010). Reconsidering Baron and Kenny: Myths and truths about mediation analysis. Journal of consumer research,

37(2), 197-20 